ROCZNIKI TEOLOGICZNE

Volume 65, issue 7 - 2018

Englis h version

DOI: http://dx.doi.org/10.18290/rt.2018.65.7-3en

PIOTR JASKÓŁA

\title{
THEOLOGICAL POST-CALVINISM
}

\begin{abstract}
The article first presents several theories illustrating John Calvin's influence on the contemporary theological legacy of his teaching. Four levels of visible influence are then enumerated. These in turn are linked to the development of Reformed orthodoxy, Puritanism, neoorthodoxy, and liberation theology.
\end{abstract}

Keywords: Calvinism; predestination; Reformed orthodoxy; Puritanism; neo-orthodoxy; liberation theology.

Some of the judgments concerning the influence of John Calvin's (15091564) thought on the modern era sound exaggerated. It can hardly be denied, however, that reformers, including John Calvin as a "second-generation reformer," initiated a movement in Europe that led to profound and still perceptible changes in many dimensions of religious and ecclesial life as well as theology. In the present article several examples of development and transformations of Calvin's theological thought will be discussed.

\section{CALVINIST ORTHODOXY}

It is astonishing that Calvin's direct successors are rarely mentioned as his actual successors. This is because many have doubts about whether they interpreted and developed the Reformer's thought in an appropriate way. Theodore Beza (1519-1605), who was the first to take over Calvin's heritage in Geneva, went in a direction, referred to as "Reformed scholasticism," "Reformed orthodoxy," or "Calvinist orthodoxy." He began to establish schools that

Rev. Prof. Piotr JASKóŁA, PHD, DSC - Head of the Institute of Ecumenism and Research at the Faculty of Theology, University of Opole, Poland, Head of the Department of the Theology of PostReformation Churches; address for correspondence-e-mail address: pj@ uni.opole.pl

${ }^{1}$ Christopher ElwoOD, Calvin für zwischendurch (Göttingen: Vandenhoeck \& Ruprecht, 2001), 165. 
were meant to reinforce Reformed teaching. An independent system of thinking and doing theology was supposed to protect against the influence of other systems and schools. Paradoxically, defenders of Reformed beliefs used instruments that Calvin had rejected. These instruments used by Reformed orthodoxy included Aristotle's philosophy, strictly logical methods of argumentation, and arguments derived from theological deduction. Whereas the method applied by Calvin was based mainly on rhetorical means of persuasion, what his scholastic heirs found more convincing was methods based on logical evidence. ${ }^{2}$ This methodical shift translated into a shift of emphasis in the contents of teaching.

Reformed scholastics tried to show the truths of Christian faith taking the Divine origin of the Bible as the point of departure. It was only on this basis that they tried to develop specific elements of their own theological system. This is particularly visible in the case of teaching on predestination, which Reformed scholastics emphasized more strongly than Calvin himself. Whereas according to the Reformer from Geneva the doctrine of predestination was supposed, in a practical way, to inspire trust in God's generosity and to highlight His sovereignty over all creation, Calvin's impatient successors made this doctrine the key to a systematization of theological ideas. While Calvin wanted the doctrine of predestination primarily to explain in what way grace affects us, Calvinist scholastics made this doctrine part of the knowledge about the essence of God. In their opinion, since the decrees of God's eternal will were made "before" the act of creation, Adam and Eve's sin, and Christ's coming, is it not right to begin the account of the world's history from this particular doctrine and to see predestination as the key to resolving all theological issues? ${ }^{3}$

In 1618, at the Synod of Dort in the Netherlands, the significance attributed to the doctrine of predestination inspired establishing the standard of orthodox Calvinist teaching. It was then that the Reverend Jacob Arminius (1560-1609) questioned the doctrine of predestination. He feared that the undermining of human freedom, which accompanies predestination, denies man the influence on his own salvation and leads to moral complacency. Arminius believed that grace was God's proposal that man could reject. According to him, those who received God's grace were free to choose to accept or reject

\footnotetext{
${ }^{2}$ Cf. ibid.

${ }^{3}$ Cf. ibid. See: Tadeusz J. ZIELIŃSKI, Iustificatio impii. Usprawiedliwienie „sola fide” jako główny artykut wiary protestancko-konserwatywnego nurtu Kościoła Anglii na przykładzie teologii Alistera E. McGratha, Jamesa I. Packera oraz Johna R. W. Stotta (Warszawa: Chrześcijańska Akademia Teologiczna, 2002), 92-105; Georg Plasger, Johannes Calvins Theologie-Eine Einführung (Göttingen: Vandenhoeck \& Ruprecht, 2008), 89-96.
} 
it, and God's eternal will is for the faithful to be saved. Changing the Calvinist doctrine of predestination, Arminius quickly won himself many supporters. As for his opponents, they believed that his teaching challenged the basic tenet of the Reformed evangelical faith. They charged him with filo-Catholicism and limiting God's freedom. ${ }^{4}$ Arminius' conception indeed created more room for human freedom than Calvin's did. It also absolved God of the charge, levelled by Jérôme-Hermès Bolsec, that He was the source of human sin. ${ }^{5}$

The cost of attributing freedom to man was the loss of the Calvinist idea of God's grace as omnipotent in all determinants of human life. At the Synod of Dort, the Calvinist church assembly declared for the first time that Christ died only for the elect. The consequences of adopting the Synod's resolutions was the unambiguous position in favour of predestination as well as the rejection of all ideas of human freedom or possibility of human cooperation with God's grace. ${ }^{6}$

"The spirit of Dort" became the "self-awareness" of the people of the seventeenth-century Reformation, who were very strongly aware of their election, and who nevertheless tried not only to see their status of the elect as a reason for religious complacency but also to find satisfaction in bearing witness to God's glory in everyday life. ${ }^{7}$

Contemporary Reformed theologians are not unanimous in their assessment of Reformed scholastics. Some see Reformed orthodoxy as a departure from Calvin's thought, while others see it as a stage in the evolution of his thought. Advocates of the evolution theory believe that Calvin's followers preserved the contents of his theological legacy and only changed his methods. Others see the resolutions of Dort as a manifest departure from Calvin's thought, since the change of method also led to a change in the contents. They argue that Calvin countered scholastic theological methods and excessive links between theology and philosophy. He tried to introduce his followers more directly to the world of the Bible than to ossified theological systems that were only supposed to play an ancillary role in the interpretation and defence of biblical truths.

\footnotetext{
${ }^{4}$ Cf. Constanzo Brovetto, Luigi Mezzadri, Fulvio Ferrario, and Paolo Ricca, Historia duchowości, vol. V: Duchowość chrześcijańska czasów nowożytnych, trans. Ewa Dobrzelecka (Cracow: Homo Dei, 2005), 445ff.

${ }^{5}$ Cf. ibid., 167.

${ }^{6}$ Cf. ibid., 168.

${ }^{7}$ Cf. ibid., 446ff.
} 


\section{PURITANISM - THE AMERICAN FORM OF CALVINISM}

A distinctive form of Calvinism was created by English Calvinists who emigrated to America at the beginning of the $17^{\text {th }}$ century. Some theologians believe that it is the paradigmatic form of Calvinism, for which the spirituality of lay asceticism was particularly important. Max Weber writes about it thus: "The God of Calvinism demanded of his believers not single good works, but a life of good works combined into a unified system. The moral conduct of the average man was thus deprived of its planless and unsystematic character and subjected to a consistent method for conduct as a whole."

In Puritans' religiosity the main assumptions of Calvin's theological thought are visible in various ways. Firstly, they followed the Reformer in placing emphasis on internal religious experience - they tried to link the knowledge of God with self-knowledge. They tried to discern the hidden internal work of the Holy Spirit in the emotional sphere and in the needs of the human heart. As in the case of Calvin, however, the Puritan emphasis on the emotional sphere did not undermine the role and significance of the human mind. The Puritans cared about broadly understood schooling and saw the need for education to ensure that man could serve God with all his personality. ${ }^{9}$

Secondly, the Puritans adopted Calvin's characteristic "spirit of struggle," or even outdid the Reformer in terms of this attitude, which is exemplified by their attitude towards the Anglican episcopal system. They were definitely uncomfortable about the conservatism of the Church of England; consequently, they placed the fight with the liturgical remains of Catholicism, particularly with bishops' authority, at the centre of their Reformed programme.

Thirdly, the Puritans followed Calvin in trying to give their faith a specific social and cultural form. In the $17^{\text {th }}$ century they achieved a profound synthesis of prayer and work, perfectly summed up by one of them: "One of the greatest sins, which results in a waste of time, is laziness or indolence... Tomorrow is a lazy man's working day, while today is his resting day... It is precisely those who do their work indolently that, later, cannot find time for religious observances. Devote your day to diligent work and you shall see that you will be able to find time also for prayer and for reading the Holy

\footnotetext{
${ }^{8}$ Max Weber, The Protestant Ethic and the Spirit of Capitalism, chap. 5, par. 30, trans. Talcott Parsons and Anthony Giddens, https://www.marxists.org/reference/archive/weber/protestant-ethic/ index.htm (accessed: 20.01.2018).

${ }^{9}$ Cf. Elwood, Calvin für zwischendurch, 169-172; Alister E. McGrath, Jan Kalwin, trans. Jerzy Wolak (Warszawa: Wydawnictwo Naukowe „Semper,” 2009), 361-364.
} 
Bible." ${ }^{10}$ Secularized Protestantism, which retained nothing of the faith of the fathers except activism transformed into business-focused rapacity, was to appear later.

Puritans' piety was far from individualism. Like Calvin, they believed that a Christian in the world called to bear witness and to build a community of faith that changes this world. The Puritans understood emigration to New England as part of their religious mission of changing the world. They wanted to build the New Jerusalem, "a city set on a mountain" (Mt 5:14). Their spirituality is sometimes referred to as "the Promised Land spirituality." 11 Setting off for a completely new world was a new social and religious project, but the experience was derived from the experiment that Calvin had applied in the "old world," in Geneva. Moreover, this missionary project was easily inspired by the Calvinist understanding of Divine Providence and the idea of predestination. God, who elects and calls his people, makes this people His instrument in the evangelization of new lands all over the world.

The Puritan understanding of calling - the striving for sanctification in the domain of social activity-is an important and clear sign of Calvin's spiritual legacy. Even if the Puritans, like many utopianists before and after them, were unable to achieve all their goals in the socio-economic world of America, it can be assumed, with a high degree of probability, that their aspirations settled in the American soul and continue to be reflected in various ways in the religious and secular domains. Many contemporary Americans consider themselves to be a special nation that wishes to serve as an example for others. Numerous elements of American politics-done from leftist as well as rightist perspectives - are pervaded by the Puritan and Calvinist ambition of building a society governed by law and justice. To this day, many figures involved in America's political life, international politics, and internal politics - regardless of whether they are Protestants, Catholics, Jews, or agnostics - can be considered as children of the Puritans and the Reformer of Geneva.

\section{THE NEW ORTHODOXY}

In the first half of the $20^{\text {th }}$ century, a new movement was born in Protestant circles, attempting to free theology from extreme tendencies, both liberal

\footnotetext{
${ }^{10}$ Translated from: BrovetTo, MEZZADRI, FerRARIo, and RicCA, Historia duchowości, vol. V, 448.

${ }^{11}$ Ibid., 452.
} 
and fundamentalist. This movement drew inspiration from Calvin's thought and from the thought of other reformers; its leader was Karl Barth (18861968), a Reformed theologian from Basel. Barth began his scholarly career from strong opposition to what he called the "wrong decision" (Fehlentscheidung) of theological liberalism. According to Barth, liberalism made evangelical theology dependent on culture and mixed the word of God with the human word. The figure he criticized particularly strongly was Friedrich Schleiermacher (1768-1834), "the father of modernist theology," who wanted to build theology using the anthropological method. ${ }^{12}$ Barth believed that liberal theologians departed from the revealed biblical teaching, which had been so important to Luther or Calvin. He therefore decided that his main task was to restore to the revealed teaching the significance it deserved. In their attempts to fulfil this task, Barth and his followers were far from fundamentalist positions.

For Barth, the Bible is the word of God not because it is free from errors - he actually saw many of them in the Bible-but because it points to Jesus Christ as the ultimate Word of God. Although in Barth's early theology God is presented as "totally Other" (ganz Anderen), which echoes the perspective known from Søren Kierkegaard's philosophy, later this theology more and more clearly places Jesus Christ in the centre in all issues, which can be attributed to inspirations derived from within Barth's own Church, including John Calvin. But Barth, who often relied on Calvin's thought, largely profiled the Reformer in such a way as to make him useful against the assumptions of liberal theology. Wherever Calvin's theology did not unambiguously support Barth's proposals-for instance, in disquisitions on the natural knowledge of God-the Basel theologian assumed that Calvin would surely have tolerated the minor corrections to his thought. In the case of other issues, such as predestination, Barth did not hesitate to claim that Calvin understood predestination in a totally wrong way because he did not identify the implications of the Christocentric understanding of God clearly enough. According to Barth, the predestining God is Christ, who took the entire burden of damnation upon himself instead of damning all mankind or part of it and who became the image of a gracious God, in whom all humanity

\footnotetext{
${ }^{12}$ See: Marcin HinTz, Etyka ewangelicka i jej wymiar eklezjalny (Warszawa: Chrześcijańska Akademia Teologiczna, 2007), 100-108; Piotr JASKÓŁA, Panem jest Duch (Opole: Wydział Teologiczny UO, 2000), 117-130; Bogusław MILERSKI, Z problemów hermeneutyki protestanckiej (Łódź: Wydawnictwo Ewangelickie św. Mateusza, 1996), 70-75.
} 
was elected. ${ }^{13}$ Thus, Barth's theology took a serious approach to the Augustinian conception of grace, which occupied a central place in Calvin's thought as well. ${ }^{14}$

\section{LIBERATION THEOLOGY}

Towards the end of the $20^{\text {th }}$ century, the neo-orthodox consensus in Reformed evangelical theology seemed to be falling apart. It began to give way to various theological movements, none of which was able to gain a dominant position. One perspective, however, appears to be worth highlighting: the "perspective of liberating man from the structures of slavery." the differences between them, liberation theologies from South America, Africa, and Asia, feminist theology, and African-American theologies do have certain elements in common. For the purposes of the topic under discussion, the question is as follows: in these theologies, can elements of Calvin's methodology be found that make it possible to interpret Christian faith in its new framework of liberation theology? It seems they can!

First of all, as is the case with Calvin, the methods of the different liberation theologies are based on the concept of sin. Although they define sin in a way that would probably have been unacceptable to Calvin, they do share the view that sin-either defined in traditional terms, as in Calvin, or understood as the structural "sin of the world," e.g. racism or sexism-is constantly present in the world, being a dimension of human existence that is difficult to understand or accept.

${ }^{13}$ See: Karl BARTH, Kirchliche Dogmatik, vol. II/2 (Zollikon-Zürich: Evangelischer Verlag, 1959), 1-563, esp. 101-214; Alfons Nossol, Chrystologia Karola Bartha (Lublin: Redakcja Wydawnictw KUL, 1979), 62ff.; Piotr JASKÓŁA, Spiritus Effector. Nauka Jana Kalwina o roli Ducha Świętego w misterium zbawienia. Studium dogmatyczno-ekumeniczne (Opole: Wydawnictwo Św. Krzyża, 1994), 142-151.

${ }^{14}$ In the mid- $20^{\text {th }}$ century, K. Barth's theology contributed to a renewed interest in Calvin's thought in the American continent. Those who sympathized with Barth's thought noticed that the Basel theologian led Calvin's thought and the thought of other classical Protestant theologians from the dead end that liberal theology had driven it into. Barth's followers and supporters of what is called dialectical theology, known in the United States as neo-orthodoxy, included Reinhold Niebuhr (18921971) and Richard Niebuhr (1894-1963). These two theologians, also belonging to the Reformed tradition, shared Barth's anxiety about the dead end that evangelical theology had been driven into by liberalism. They were, however, not so strong as Barth was to oppose the liberal tradition equally forcefully. Besides, the American reception of Calvinism largely accepted the positive assessment of human experience as a source of theology. Cf. Elwood, Calvin für zwischendurch, $178 \mathrm{ff}$.

${ }^{15}$ Ibid., 179. 
Secondly, in Calvin's theology there is a special "spirit of criticism," so characteristic of liberation theology. Liberation theologians try to name all forms of sin that go against genuinely human life. This practice of naming sin is nearly always combined with the criticism of certain forms of culture, social life, church structures, and inherited theological methods. The Calvinist understanding of freedom and responsibility in prophetic criticism is reflected in liberation theology. This also makes it clear that Calvin did not restrict the Christian message of salvation to the individual soul. He was convinced that the biblical message is a call for building the Church as a biblical community of law and justice. ${ }^{16}$

Thirdly, liberation theologians tried to embed their postulates and ideas about Christian faith in social reality, with the aim of liberating entire social groups from enslaving conditions. In the case of liberation theologians it is possible to see a passionate desire to introduce new forms of interpersonal coexistence - a desire that also inspired Calvin's introduction of reforms in Geneva. Calvin's successors tried to change the world for the better, too. Even if Calvin's influence on liberation theology is not directly and clearly visible in every case, many liberation theologians worked, like Calvin, with a prophetic belief that Christians' calling and mission is to build a visible "God's state." 17

The legacy of John Calvin's theological thought is not only rich and diverse but also marked by opposing tendencies. Paradoxically, on the one hand it is possible to see Calvin as a reformer criticizing ossified dogmas, a humanist calling for tolerance and openness to mystery in a broad sense of the term; on the other hand, it is possible to see him as a man who-in the chaotic time of entering the modern era, in the period marked by the division of the Church and the collapse of various ordering structures - was filled with human anxiety and, as a conservative, saw the need to struggle for the preservation of order in the world.

It seems that today the legacy of John Calvin's theological works can be observed and assessed most accurately on the basis of Reformed theologians' thought and the activity of Reformed churches. For all its diversity, both contemporary Reformed theology and the activity of churches rooted in

\footnotetext{
${ }^{16}$ Cf. Elwood, Calvin für zwischendurch, 181.

${ }^{17}$ Ibid.
} 
the Reformed tradition seem to be responding appropriately to changes in the world: they engage in various evangelization programmes as well as take part in the ecumenical movement and doctrinal dialogues without losing their Calvinist identity.

\section{BIBLIOGRAPHY}

BARTH, Karl. Kirchliche Dogmatik, vol. II/2. Zollikon-Zürich: Evangelischer Verlag, 1959.

Brovetto, Constanzo, Luigi Mezzadri, Fulvio Ferrario, and Paolo Ricca. Historia duchowości [A history of spirituality]. Vol. V, Duchowość chrześcijańska czasów nowożytnych [Christian spirituality of modern times]. Translated by Ewa Dobrzelecka OSsR. Cracow: Homo Dei, 2005.

Elwood, Christopher. Calvin für zwischendurch. Göttingen: Vandenhoeck \& Ruprecht, 2001.

HINTZ, Marcin. Etyka ewangelicka i jej wymiar eklezjalny [Evangelical ethics and its ecclesial dimension]. Warszawa: Chrześcijańska Akademia Teologiczna, 2007.

JASKÓŁA, Piotr. Panem jest Duch [The Spirit is the Lord]. Opole: Wydział Teologiczny UO, 2000.

JASKÓŁA, Piotr. Spiritus Effector. Nauka Jana Kalwina o roli Ducha Świętego w misterium zbawienia. Studium dogmatyczno-ekumeniczne [Spiritus Effector. John Calvin's teaching on the role of the Holy Spirit in the mystery of salvation. A dogmatic and ecumenical study]. Opole: Wydawnictwo Św. Krzyża, 1994.

McGrath, Alister E. Jan Kalwin [A Life of John Calvin]. Translated by Jerzy Wolak. Warszawa: Wydawnictwo Naukowe „Semper,” 2009.

MilersKI, Bogusław. Z problemów hermeneutyki protestanckiej [Selected issues of Protestant hermeneutics]. Łódź: Wydawnictwo Ewangelickie św. Mateusza, 1996.

Nossol, Alfons. Chrystologia Karola Bartha [Karl Barth's Christology]. Lublin: Redakcja Wydawnictw KUL, 1979.

Plasger, Georg. Johannes Calvins Theologie-Eine Einführung. Göttingen: Vandenhoeck \& Ruprecht, 2008.

Weber, Max. The Protestant Ethic and the Spirit of Capitalism. Translated by Talcott Parsons and Anthony Giddens, https://www.marxists.org/reference/archive/weber/protestant-ethic/index.htm (accessed: 20.01.2018).

ZIELIŃSKI, Tadeusz J. Iustificatio impii. Usprawiedliwienie „sola fide” jako główny artykuł wiary protestancko-konserwatywnego nurtu Kościoła Anglii na przyktadzie teologii Alistera E. McGratha, Jamesa I. Packera oraz Johna R. W. Stotta [Iustificatio impii. Justification "sola fide" as the main article of faith in the conservative Protestant wing of the Church of England as exemplified in the theology of Alister E. McGrath, James I. Packer, and John R.W. Stott]. Warszawa: Chrześcijańska Akademia Teologiczna, 2002.

\section{Translated by Piotr Czyżewski}

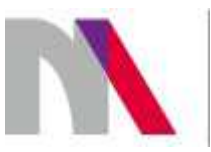

The preparation of the English version of Roczniki Teologiczne (Annals of Theology) and its publication in electronic databases was financed under contract no. 836/P-DUN/2018 from the resources of the Minister of Science and Higher Education for the popularization of science. 